\section{Juin 1994}

\section{S.O.T.EST 1994}

\section{attention changement de dates!}

La Réunion annuelle 1994 de la S.O.T.EST aura lieu à Lons-le-Saunier du vendredi 17 au dimanche 19 juin 1994.

Ce changement de dates a été rendu nécessaire par suite de chevauchements avec d'autres manifestations.

Sujets des Tables Rondes :

- Fractures ouvertes de jambe type III

- Arthroplasties totales de hanche compliquées de fracture du fémur.

Organisateurs : Pr Ph. Vichard et Pr Y. Tropet (Besançon)

\section{Octobre 1994}

\section{Congrès A.S.A.M.I.-F. 1994 \\ Association pour l'étude Systématique et l'Application de la Méthode d'Ilizarov - France}

\section{Lille, 7-8 octobre 1994}

IIIème cours supérieur :

Sujet : La méthode d'Ilizarov, 10 ans après. Etat actuel et indications spécifiques de la méthode d'Tlizarov.

Dates limites de demandes de communication : 15 avril 1994

Dates limites d'envois de textes : 15 juin 1994

Renseignements : Pr B. Vinchon, 1, boulevard de la Liberté, F-59800 Lille, Tél. 20.57.05.24, Fax 20.54.63.36

\section{Congress A.S.A.M.I.-F.}

\section{Lille, France, October 7-8, 1994}

3rd advanced course

Topics: Ilizarov method 10 years after. State of art, limb lengthening, correction of angular deformations, congenital deformities, traumatology and sequellae. Free papers

\title{
Analyses de livres
}

\section{Scores, Bewertungsschemata und Klassifikationen in Orthopädie und Traumatologie}

K.-L. Krämer, F.-P. Maichl (1993) Thieme Verlag, Stuttgart New York, DM 98 (en allemand)

Cet ouvrage constitue une véritable bible des scores fonctionnels et des classifications.

Voulez-vous, par exemple, étudier la fonction de l'articulation scapulohumérale avant et après chirurgie ou bien après un accident ? Vous aurez le choix entre une trentaine de scores en fonction des diverses pathologies: fonction globale, lésions de la coiffe des rotateurs, luxation de l'épaule, arthroplastie d'épaule, disjonction acromio-claviculaire, impingement syndrome, fractures de l'humérus. Cet exemple de la chirurgie de l'épaule est multiplié pour toute la pathologie de l'appareil locomoteur.

\section{Scores, Patterns and Classifications in Orthopaedics-Trau- matology (in German)}

This book constitutes a real bible of functional scores, patterns and classifications.

Do you wish, for example, to study the function of the scapulo-humeral articulation before and after surgery or after an accident? You will have the choice between about thirty scores depending on various pathologies; global function, rotator cuff tear, shoulder dislocation, shoulder arthroplasty, acromio-clavicular dysfunction, impingement syndrome, fractures of the humerus.
Les auteurs de classifications et de scores sauront rapidement s'ils ont été retenus dans l'ouvrage en consultant l'index des auteurs et l'on trouvera les entrées pathologiques dans une liste alphabétique des sujets traités.

Indispensable à tous ceux qui veulent comparer des fonctions, des résultats et indiquer queile classification ils ont retenue : experts, rédacteurs de rapports, étudiants, c'est-à-dire en fait tous les orthopédistes traumatologues. L'ouvrage mériterait une traduction anglaise et française.

P. Kehr

This example of shoulder surgery is multiplied for pathology of the whole locomotor apparatus.

The authors of scores and classifications will quickly know if they have been included in the book by consulting the index of authors and one finds the pathologic entries within an alphabetical order list of subjects treated.

Indispensable to all those who wish to compare functions, results, and indicate which classification they have used: experts, editors of reports, students, i.e. in fact all the traumatology orthopaedists.

An English and French translation of the book would be worthwhile. 